\title{
Efficacy and microbial responses of biochar-nanoscale zero-valent during in-situ remediation of Cd-contaminated sediment
}

\section{A R T I C L E I N F O}

\section{Article history:}

Received 30 June 2020

Received in revised form

4 November 2020

Accepted 9 November 2020

Available online 12 November 2020

Handling Editor: Prof. Jiri Jaromir Klemeš

\section{Keywords:}

Cadmium (Cd)

Sediment immobilization

Nanoscale zero-valent ion

Biochar

Bacterial communities

\begin{abstract}
A B S T R A C T
In situ immobilization of heavy metals in sediments has been considered as a low-cost and eco-friendly remediation method. In this study, biochar $(\mathrm{BC})$ and $\mathrm{BC}$-nanoscale zero-valent iron composite (nZVI/BC) treatments with different doses were conducted to immobilize $\mathrm{Cd}$ in sediments in situ. The performance of $\mathrm{BC}$ and $\mathrm{nZVI} / \mathrm{BC}$ in changing $\mathrm{Cd}$ mobility and bacterial community in sediment was investigated, and their remediation efficiencies at various $\mathrm{pH}$ values were also explored. After $140 \mathrm{~d}$ of remediation, the results showed that the application of $\mathrm{BC}$ and $\mathrm{nZVI} / \mathrm{BC}$ reduced the released $\mathrm{Cd}$ concentrations in the overlying water and porewater by $31-69 \%$ and $26-73 \%$, respectively. Compared to the control, the labile $\mathrm{Cd}$ in treated sediments was transformed to a stable fraction, and the TCLP (toxicity characteristic leaching produce) extracted $\mathrm{Cd}$ decreased by $7-29 \%$. The reduction in $\mathrm{Cd}$ mobility was closely related to the additional dose of $\mathrm{BC}$ or $\mathrm{nZVI} / \mathrm{BC}$, and the presence of nZVI greatly enhanced the ability of $\mathrm{nZVI} / \mathrm{BC}$ to stabilize $\mathrm{Cd}$. Notably, nZVI/BC presented a higher restriction for $\mathrm{Cd}$ release from sediment than $\mathrm{BC}$ at various $\mathrm{pH}$ values, and both $\mathrm{BC}$ and $\mathrm{nZVI} / \mathrm{BC}$ showed the highest remediation effects under alkaline condition. Bacterial community analysis indicated that the richness and diversity of bacterial communities with the low-dose treatments were enhanced, while inhibition was observed at high dose treatments due to changes in the $\mathrm{pH}$ and toxicity of $\mathrm{BC}$ and $\mathrm{nZVI} / \mathrm{BC}$. This study supplies new insights into the potential effects of $\mathrm{BC}$ and $\mathrm{nZVI} / \mathrm{BC}$ application on $\mathrm{Cd}$ in situ immobilization in contaminated sediments. (c) 2020 Elsevier Ltd. All rights reserved.
\end{abstract}

\section{Introduction}

Heavy metal pollution has caused wide concern around the world because of its high toxicity, persistence, nonbiodegradability, and bioaccumulation (Liu et al., 2018a). Cadmium (Cd) is a widespread heavy metal in sediments, and presents higher mobility and toxicity compared to other heavy metals (Liu et al., 2020a). Cd can enter and accumulate in the human body via the food chain, thereby exerting various adverse effects on bone and kidney and even increasing cancer risks (Zhao et al., 2017). Sediment plays an important role in storing and transporting toxic metals in aquatic ecosystems (Liu et al., 2018a). The accumulated heavy metals in surface sediment always tend to be released to overlying water with changes in environmental factors, causing damage to aquatic organisms and human health (Li et al., 2019). Therefore, it is urgent

\footnotetext{
* Corresponding author.

E-mail address: yqsheng@yic.ac.cn (Y. Sheng).
}

to remediate Cd-polluted sediments.

To date, various techniques have been developed for the remediation of heavy metal-contaminated sediments, such as landfilling and disposal, electrochemical remediation, washing, and phytoremediation (Wang et al., 2019). Nevertheless, these techniques have some drawbacks: landfilling and disposal can cause land wastage and groundwater pollution (Wang et al., 2015); electrochemical remediation and washing are restrained by application scale and cost burden (Beiyuan et al., 2017); and phytoremediation takes too much time, and requires further treatment ( $\mathrm{Li}$ et al., 2019). In comparison, in situ immobilization has been considered as a cost, time-effective, and eco-friendly method compared to the methods above (Liu et al., 2020a). For in situ immobilization of heavy metals, the selection of immobilization materials is crucial. Nanoscale zero-valent iron (nZVI) has attracted extensive attention in removing heavy metals owing to its high reactivity and low toxicity (Yang et al., 2018). However, nZVI particles tend to easily gather because of their small particle size and large specific surface area, thus decreasing their ability to remove 
heavy metals (Huang et al., 2016). To inhibit agglomeration, synthesized nZVI particles have been commonly loaded with specific surface modifying materials (Cai et al., 2019). Biochar (BC), produced by pyrolysis of biological waste, is a low-cost, porous carrier, and has a large specific surface area of carbon-based material (Li et al., 2020a). Meanwhile, BC is considered as an effective material to disperse nZVI to reduce its agglomeration (Luo et al., 2019). Furthermore, BC is also a frequently used remediation material for heavy metal removal via adsorption and complexation (Liu et al., 2018b). However, the ability of BC alone to remove heavy metals is limited, and sometimes its removal effect of heavy metals is not satisfactory (Li et al., 2020b). Thus, it seems to be a very promising choice to modify BC with nZVI to improve its adsorption capacity. In fact, a previous study reported that a corn stalk BC-nZVI composite (nZVI/BC) showed a higher removal efficiency for $\mathrm{Cu}, \mathrm{Zn}$, and $\mathrm{Pb}$ compared to raw BC in wastewater (Yang et al., 2018). Moreover, as reported by Liu et al. (2020a), nZVI/BC posed lower toxicity to the bacterial community in sediment; conversely, the diversity and richness of the bacterial community was enhanced after nZVI/BC treatment. Therefore, the application of nZVI/BC for in situ sediment remediation is also environmentally friendly. Overall, further study of the in situ immobilization of Cd-polluted sediment using $\mathrm{nZVI} / \mathrm{BC}$ is promising and practical.

In situ immobilization aims to reduce the mobility and bioavailability of heavy metals in sediments to decrease the risk of exposure or release (Li et al., 2019). In fact, sediment conditions are always variably influenced by external factors, which may affect the behavior of heavy metals in remediated sediments. Therefore, in situ immobilization of heavy metals in sediments could be interfered by changes in external environmental conditions. Generally, $\mathrm{pH}$ is a sensitive factor for the behavior and mobility of heavy metals in sediments, and low pH can enhance their mobility because of increased cation exchange and competitive adsorption (Liu et al., 2020b). Thus, changes in the acidity of natural water bodies may affect the durability of remediation materials and even lead to the failure of remediation. Therefore, acidity resistance and long-term stability of heavy metals in sediment under in situ immobilization should be further demonstrated. However, there are very limited studies focusing on the efficacy and vitality of remediation materials during in situ immobilization. Microbial communities can not only reflect sediment quality but also show the toxicity and bioavailability of heavy metals, thus indicating an in situ Cd immobilization effect (Xue et al., 2018a). For example, according to our previous study (Liu et al., 2020a), the application of $\mathrm{BC}$ and $\mathrm{nZVI} / \mathrm{BC}$ for $90 \mathrm{~d}$ reinforced the diversity and richness of microbial communities in sediments and promoted the Cd stabilization by enhancing the relative abundances of sulfate-reducing bacteria. However, the changes in the bacterial community in $\mathrm{Cd}-$ contaminated sediments treated with different doses of $\mathrm{BC}$ (or $\mathrm{nZVI} / \mathrm{BC}$ ) and longer-term treatments are still unclear.

The aims of the present study are to (1) investigate the remediation effects of $\mathrm{BC}$ and $\mathrm{nZVI} / \mathrm{BC}$ on Cd-contaminated sediments; (2) assess the effect of varying $\mathrm{pH}$ values on $\mathrm{Cd}$ release from sediment during the in-situ remediation process; and (3) study the responses of the sediment microbial community under different doses and longer-term BC and nZVI/BC treatments. This study has provided scientific insights for an eco-friendly and effective method to immobilize Cd-contaminated sediment in situ.

\section{Materials and methods}

\subsection{Sediment descriptions}

The surface sediments $(0-10 \mathrm{~cm})$ were sampled from Guangdang River (Yantai City, China). As an urban river, the Guangdang
River has been suffered from heavy metal pollution owing to the discharge of domestic and industrial wastewater along the river (Liu et al., 2020a). The collected sediment was air-dried and passed through a 100 -mesh nylon sieve to get a homogenous sample. One part of the homogenous sediment was used to determine its physicochemical characteristics (Table S1), and the rest was used for the immobilization experiment. The detailed determination methods are supplied in Supporting Information Text S1. The results indicated that the sediment was heavily contaminated by $\mathrm{Cd}$.

\subsection{Preparation and characterization of immobilization materials}

According to the study of Liu et al. (2020a), the rice straw BC was prepared by fast pyrolysis for $10 \mathrm{~s}$ at $500{ }^{\circ} \mathrm{C}$ under inert $\mathrm{N}_{2}$ purging. The obtained $\mathrm{BC}$ was oven-dried at $85{ }^{\circ} \mathrm{C}$ for $24 \mathrm{~h}$ and passed through a 100-mesh nylon sieve. nZVI/BC was synthesized following a previous report provided in Supporting Information Text S2 (Liu et al., 2020a), and the mass ratio of nZVI to BC was 1:5. The $\mathrm{pH}$ of $\mathrm{BC}$ and $\mathrm{nZVI} / \mathrm{BC}$ was measured at a ratio of $1: 5(\mathrm{w} / \mathrm{v})$. The cation exchange capacity (CEC) was analyzed with the method of Hexamminecobalt trichloride solution-Spectrophotometric (MEPC, 2017). The specific surface areas were measured using an automatic surface analyzer (Quantachrome, USA) and calculated using the Brunauer-Emmett-Teller (BET) method. The surface morphology and element distribution were analyzed by scanning electron microscopy-energy dispersive spectrometry (SEM-EDS) (S-4800, Hitachi, Japan). The organic functional groups were analyzed using Fourier transform infrared spectroscopy (FTIR, Nicolet iS50, Thermo Fisher, USA). The $\mathrm{C}, \mathrm{H}, \mathrm{O}$, and $\mathrm{N}$ contents were determined by an organic chemical element analyzer (Vario MACRO cube, Elementar, Germany). The crystal structures of BC and nZVI/BC were determined by X-ray diffraction (XRD) (Empyrean, PANalytical B.V. Netherlands) in the range of $10-80^{\circ}$ (2 theta).

\subsection{Experimental setup}

In situ immobilization experiments were performed in 250-mL high-density polyethylene bottles containing $40 \mathrm{~g}$ of $\mathrm{Cd}$ contaminated sediments with the addition of various dosages of $\mathrm{BC}$ and $\mathrm{nZVI} / \mathrm{BC}$. The mass ratios of immobilization materials and sediment were set as $2 \%, 5 \%$, and $8 \%$ by mass. For convenience, the treatments with $2 \%, 5 \%$, and $8 \%$ added $\mathrm{BC}$ by mass were named as $2 \mathrm{~B}, 5 \mathrm{~B}$, and $8 \mathrm{~B}$, respectively; the treatments with $2 \%, 5 \%$, and $8 \%$ added $\mathrm{nZVI} / \mathrm{BC}$ by mass were named $2 \mathrm{nB}, 5 \mathrm{nB}$, and $8 \mathrm{nB}$, respectively. Afterwards, $200 \mathrm{~mL}$ of ultrapure water $(18.2 \mathrm{M} \Omega * \mathrm{~cm})$ was slightly added to the mixture. All bottles were sealed and then placed at room temperature. In addition, to test the effect of $B C$ and $\mathrm{nZVI} / \mathrm{BC}$ immobilization effects under different $\mathrm{pH}$ conditions, the experiments were also conducted at $\mathrm{pH} 3.0,5.0,7.0$, and 9.0 as previously reported (Zhang et al., 2017). In detail, $200 \mathrm{~mL}$ of overlying water adjusted to different $\mathrm{pH}$ values using $0.01 \mathrm{M} \mathrm{HNO}_{3}$ and $0.01 \mathrm{M} \mathrm{NaOH}$ was added to the mixture of $2 \mathrm{~g}$ of immobilization material (BC and $\mathrm{nZVI} / \mathrm{BC}$ ) and $40 \mathrm{~g}$ of sediment ( $5 \%$ by mass). At predetermined time intervals $(1,3,7,15,30,60$, and $140 \mathrm{~d}), 2 \mathrm{~mL}$ of overlying water was collected and analyzed for residual $\mathrm{Cd}$ concentration using an inductively coupled plasma mass spectrometer (ICP-MS, Optima 7000 DV, PerkinElmer, USA). All experiments were conducted in triplicate. The control groups were performed in the absence of immobilization materials under otherwise identical conditions.

\subsection{Sediment chemical determination}

After removing the overlying water, the $\mathrm{pH}$, total organic carbon (TOC), dissolved organic carbon (DOC), and CEC of the sediments 
were measured. The supernatant of a 1:15 (w/v) suspension extracted with ultrapure water was employed for DOC analysis, and its concentration was detected using a TOC analyzer (TOC-VCPH, Shimadzu, Japan). The analysis methods of CEC and $\mathrm{pH}$ in sediments were the same as those for BC analysis, and TOC was consistent with raw sediment analysis (Text S1). Sediments were centrifuged at $5000 \mathrm{rpm}$ for $20 \mathrm{~min}$ to receive porewater, and $\mathrm{Cd}$ concentrations in porewater were determined using ICP-MS.

\subsection{The sequential extraction procedure}

In this study, a modified Bureau Communautaire de Référence (BCR) sequential extraction was used to determine the $\mathrm{Cd}$ fraction in sediments (Liu et al., 2020b). The detailed sequential extraction procedure is presented in Table S1.

\subsection{Toxicity characteristic leaching procedure (TCLP)}

TCLP was employed to measure the leaching ability of Cd in the sediments (Liu et al., 2018b). One gram of sediment mixed with $20 \mathrm{~mL}$ of extraction solution (acetic acid solution, $\mathrm{pH}=2.88$ ) was placed in a $50 \mathrm{~mL}$ centrifuge tube and then shaken for $18 \mathrm{~h}$ at $25^{\circ} \mathrm{C}$. After centrifugation at $5000 \mathrm{rpm}$ for $30 \mathrm{~min}$, the supernatant was filtered for Cd concentration analysis. The immobilization efficiency of TCLP-leachable Cd was calculated via the following equation:

Immobilization efficiency $(\%)=\frac{\left(C_{C, T C L P}-C_{T C L P}\right)}{C_{C, T C L P} \times 0.02} \times 100 \%$

where $C_{C, \text { TCLP }}$ is the TCLP-leachable $C d$ concentration in the control $(\mathrm{mg} / \mathrm{L})$, and $C_{T C L p}$ is the TCLP-leachable Cd concentration in the treated groups $(\mathrm{mg} / \mathrm{L})$.

\subsection{Bacterial community assays}

The total genomic DNA in sediment samples was extracted with the sodium dodecyl sulfonate method (Liu et al., 2020a). Subsequently, the extracted DNA was diluted to $1 \mathrm{mg} / \mathrm{L}$ using sterile water based on the corresponding concentrations. The genomic DNA was amplified by PCR using $16 \mathrm{~S}$ rRNA gene V4 region primers. All PCRs were performed in $30-\mu \mathrm{L}$ reactions containing $15-\mu \mathrm{L}$ of Phusion ${ }^{\circledR}$ High-Fidelity PCR Master Mix, forward and reverse primers at $0.2 \mu \mathrm{M}$, and $\sim 10 \mathrm{ng}$ of template DNA. The PCR conditions were set as follows: denaturation at $98^{\circ} \mathrm{C}$ for $1 \mathrm{~min}$, then 30 cycles $\left(98^{\circ} \mathrm{C}\right.$ for $10 \mathrm{~s}, 50^{\circ} \mathrm{C}$ for $30 \mathrm{~s}, 72^{\circ} \mathrm{C}$ for $30 \mathrm{~s}$ ), and finally an extension at $72{ }^{\circ} \mathrm{C}$ for $5 \mathrm{~min}$. Agarose gel electrophoresis at $1 \%$ was used to

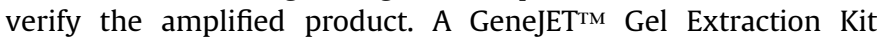
(Thermo Scientific, USA) was employed to further purify the PCR amplification product. Sequencing libraries were generated using the Ion Plus Fragment Library Kit 48 rxns (Thermo Scientific, USA). The library quality was assessed according to a Qubit@2.0 Fluorometer (Thermo Scientific, USA). Finally, an Ion S5TM XL platform was used to sequence the library.

\subsection{Statistical analysis}

Analysis of variance analysis (ANOVA) was conducted using SPSS 19 software, and the significance level was regarded as 0.05 . The canonical correspondence analysis (CCA), heatmap, and rarefaction curves were determined by $\mathrm{R}$ software. Sequences with $\geq 97 \%$ similarity were regarded as the same operational taxonomic units (OTUs). The representative sequence was received by the Silva Database based on the Mothur algorithm to sign taxonomic information. The Shannon-Wiener index and abundance-based coverage estimator (ACE) were computed by Qiime software.

\section{Results and discussion}

\subsection{Characterization of immobilization materials}

Although the characteristic peak of $\mathrm{Fe}^{\circ}$ at $2 \theta=44.9^{\circ}$ occurred in the XRD pattern of nZVI/BC (Fig. 1g), it was not found in raw BC. This illustrated that nZVI was successfully loaded with BC. Additionally, the characteristic peak of $\mathrm{Fe}_{3} \mathrm{O}_{4}\left(2 \theta=65.2^{\circ}\right)$ appeared at nZVI and $\mathrm{nZVI} / \mathrm{BC}$, demonstrating that oxidation occurred in the preparation of nZVI. The SEM-EDS images of $\mathrm{BC}$ and $\mathrm{nZVI} / \mathrm{BC}$ are shown in Fig. 1a-f. Many pore structures were observed on the surface of raw $\mathrm{BC}$ (Fig. 1a and b), which was responsible for the huge specific surface area of BC. After nZVI loading, many spherical nZVI particles existed independently instead of assembling on the BC surface (Fig. 1d and e), suggesting that the aggregation tendency of nZVI particles was reduced, and the reactivity of nZVI was greatly improved. The EDS analysis confirmed that the elemental composition of $\mathrm{BC}$ was dominated by elements $\mathrm{C}$ and $\mathrm{O}$ (Fig. 1c); for $\mathrm{nZVI} /$ $\mathrm{BC}$ (Fig. 1f), higher concentrations of Fe appeared on the nZVI/BC surface due to nZVI loading. FTIR spectra of BC and nZVI/BC were scanned in the range of $4000-400 \mathrm{~cm}^{-1}$, and the results are shown in Fig. $1 \mathrm{~h}$. The surfaces of $\mathrm{BC}$ and $\mathrm{nZVI} / \mathrm{BC}$ consisted of abundant oxygen-containing functional groups: $\mathrm{OH}\left(3426 \mathrm{~cm}^{-1}\right), \mathrm{C}=\mathrm{O}$ $\left(1573 \mathrm{~cm}^{-1}\right)$, phenolic-OH $\left(1270 \mathrm{~cm}^{-1}\right)$, and $\mathrm{C}-\mathrm{O}\left(1155 \mathrm{~cm}^{-1}\right)$ groups. These functional groups can effectively stabilize heavy metals through complexation (Liu et al., 2018b). Thus, these functional groups of $\mathrm{BC}$ and $\mathrm{nZVI} / \mathrm{BC}$ would favor the stabilization of heavy metals. Compared to $\mathrm{BC}$, the weak peaks of $\mathrm{Fe}-\mathrm{O}$ fall in the ranges of $700-500 \mathrm{~cm}^{-1}$ in the $\mathrm{nZVI} / \mathrm{BC}$ spectra. This suggested that $\mathrm{Fe}^{3+}$ produced from nZVI was successfully attached to the surface of BC by chelating with oxygen-containing groups, which confirmed the formation of iron oxides on the nZVI/BC surface (Yang et al., 2018). The iron oxides on the nZVI/BC surface can stabilize metal ions by supplying more adsorption sites, electrostatic interactions, and surface complexation (Liu et al., 2020a).

In Table 1 , the $\mathrm{pH}$ of $\mathrm{BC}$ was slightly higher than that of raw sediment ( 7.95 vs. 7.63). After nZVI loading, the $\mathrm{pH}$ of $\mathrm{nZVI} / \mathrm{BC}$ was greatly increased and was much higher than that of raw sediment (9.42 vs. 7.63 ). The $\mathrm{pH}$ increase was beneficial to $\mathrm{Cd}$ immobilization because higher $\mathrm{pH}$ enhanced metal precipitation and simultaneously reduced metal solubility (Liu et al., 2018b). Generally, the CEC of immobilization materials can reflect the ability to absorb cations (such as $\mathrm{Cd}^{2+}$ ), and a higher CEC can favor the stabilization of heavy metals (Song et al., 2017). In this work, the CEC of nZVI/BC was higher than that of $\mathrm{BC}$, indicating that the ion exchange capacity of $B C$ was strengthened after nZVI loading. This could be attributed to $\mathrm{Fe}^{3+}$ or $\mathrm{Fe}^{2+}$ being released from nZVI on the $\mathrm{BC}$ surface, resulting in a great $C E C$ increase in $n Z V I / B C$. The specific surface area of $\mathrm{nZVI} / \mathrm{BC}$ was decreased compared to raw BC (from 240.13 to $201.26 \mathrm{~m}^{2} / \mathrm{g}$ ). The reason for this was that nZVI particles loaded on the surface of BC could block the micropores of BC, causing a significant decrease in the specific surface area (Sun et al., 2019). The major elements in BC and $n Z V I / B C$ were $C, O$, and $H$; notably, the high Fe concentration presented in $\mathrm{nZVI} / \mathrm{BC}$ compared to raw BC (166.89 vs. $9.71 \mathrm{~g} / \mathrm{kg}$ ) due to $\mathrm{nZVI}$ loading on the $\mathrm{nZVI} / \mathrm{BC}$ surface.

\subsection{Effects of immobilization materials on sediment properties}

Generally, sediment properties are closely related to heavy metal behaviors and availabilities (Liu et al., 2020a). In this study, the $\mathrm{pH}, \mathrm{CEC}, \mathrm{TOC}$, and DOC presented great changes after immobilization (Fig. 2). The $\mathrm{pH}$ in all treated groups was significantly higher than that in the control except for $2 \mathrm{nB}$ (Fig. $2 \mathrm{I}, P<0.05$ ). This was due to the gradual release of alkali and alkaline-earth metals 

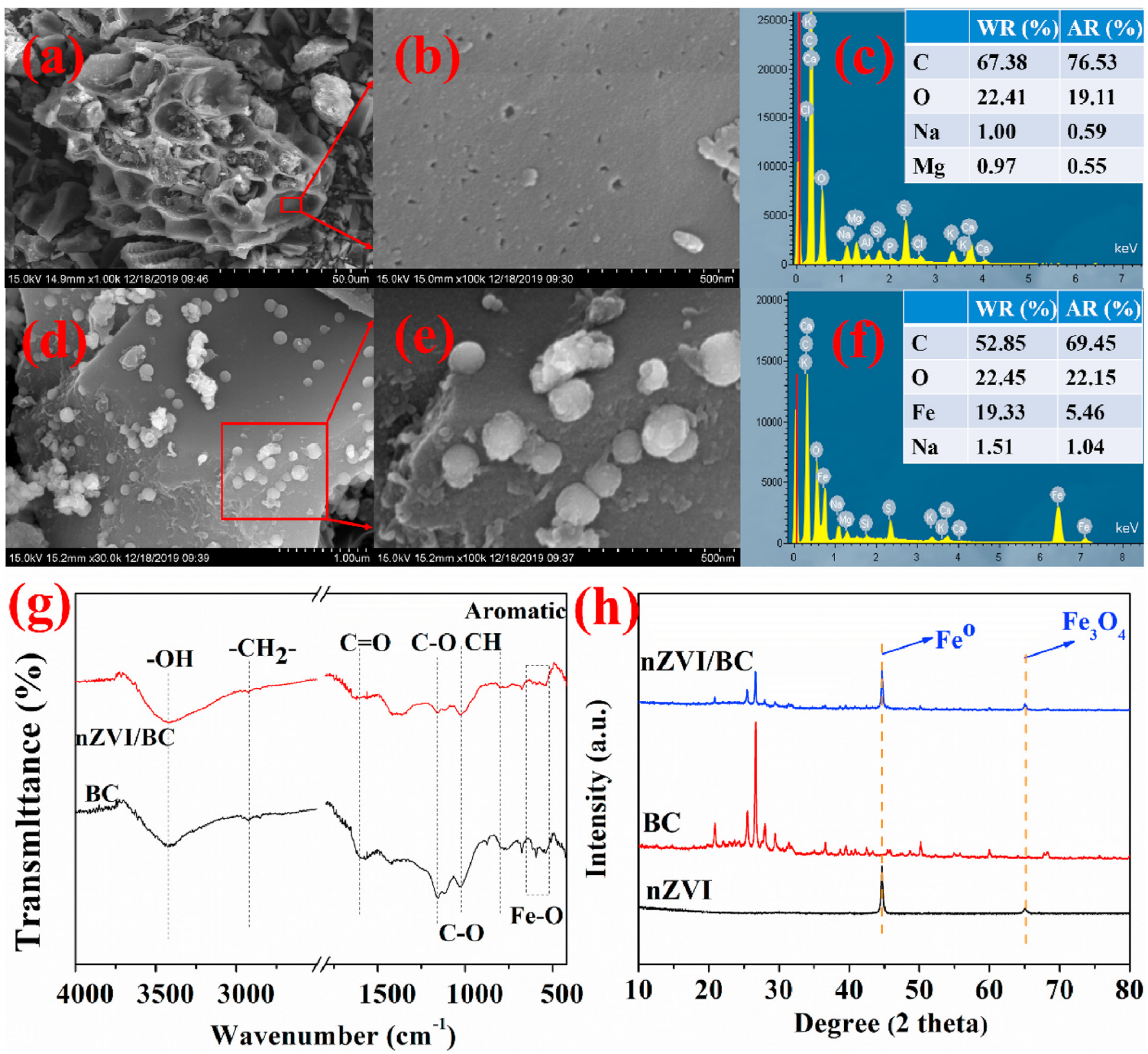

Fig. 1. SEM-EDS images of $B C(a, b$, and $c)$ and nZVI/BC (e, d, and f); XRD (g) and FTIR spectrum (h) of BC and nZVI/BC; WR: weight ratio; AR: atom ratio.

from BC or nZVI/BC (Yang et al., 2019). In addition, the $\mathrm{pH}$ in sediments most of treated by $\mathrm{nZVI} / \mathrm{BC}$ was higher than in sediments with $\mathrm{BC}$ treatments. This could be explained by $\mathrm{OH}^{-}$ions being released through nZVI oxidation based on the following reaction (Xue et al., 2018b):

$2 \mathrm{Fe}^{0}+\mathrm{O}_{2}+2 \mathrm{H}_{2} \mathrm{O} \rightarrow 2 \mathrm{Fe}^{2+}+4 \mathrm{OH}^{-}$
This result showed that the addition of $\mathrm{BC}$ and $\mathrm{nZVI} / \mathrm{BC}$ was conducive to $\mathrm{Cd}$ immobilization because high $\mathrm{pH}$ could promote the precipitation of $\mathrm{Cd}^{2+}$ and concurrently reduce its solubility (Liu et al., 2018b). Generally, CEC can reflect the retention capacity of sediment to heavy metals, and increased CEC would be beneficial to reduce the mobility of heavy metals in sediments via cation exchange (Song et al., 2017). In this study, the increases in CEC were observed in all treated groups compared to the control. This

Table 1

The physico-chemical characteristics of $\mathrm{BC}$ and nZVI/BC.

\begin{tabular}{|c|c|c|c|c|c|c|c|c|}
\hline \multirow[t]{2}{*}{ Material } & \multirow[t]{2}{*}{$\mathrm{pH}$} & \multirow[t]{2}{*}{$\mathrm{CEC}\left(\mathrm{cmol}^{+} / \mathrm{kg}\right)$} & \multirow[t]{2}{*}{ BET $\left(\mathrm{m}^{2} / \mathrm{g}\right)$} & \multirow[t]{2}{*}{$\mathrm{Fe}(\mathrm{g} / \mathrm{kg})$} & \multicolumn{4}{|c|}{ Elemental composition (\%, mass based) } \\
\hline & & & & & $\mathrm{C}$ & $\mathrm{H}$ & $\mathrm{O}$ & $\mathrm{N}$ \\
\hline $\mathrm{BC}$ & $7.82 \pm 0.03$ & $7.67 \pm 0.80$ & 240.13 & $9.71 \pm 0.18$ & 58.36 & 2.43 & 12.68 & 0.83 \\
\hline $\mathrm{nZVI} / \mathrm{BC}$ & $9.42 \pm 0.21$ & $18.58 \pm 0.56$ & 201.26 & $166.89 \pm 1.71$ & 51.76 & 2.01 & 10.27 & 0.60 \\
\hline
\end{tabular}



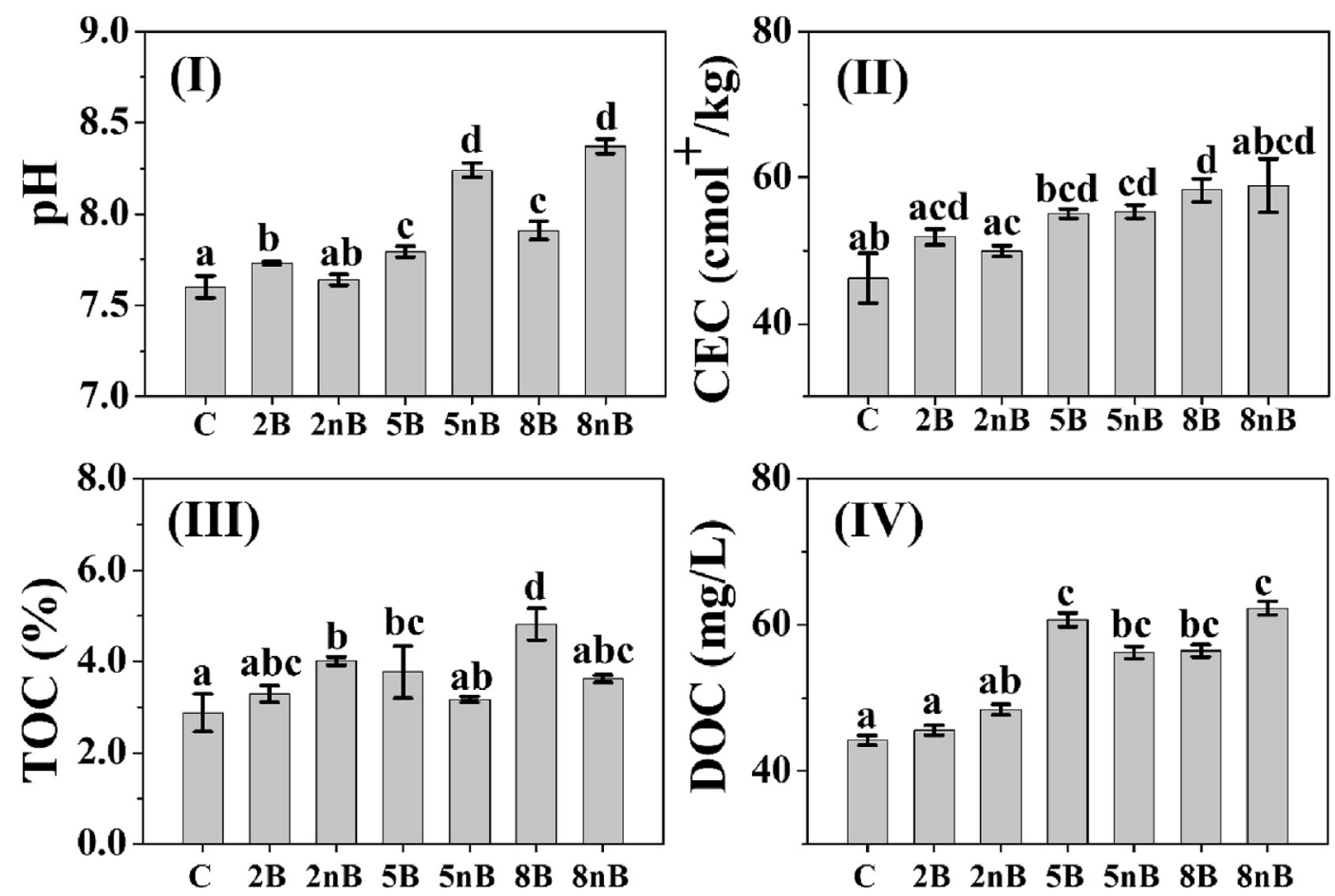

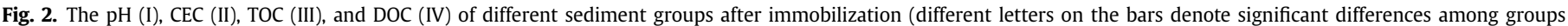
$(P<0.05))$.

phenomenon can be explained by the fact that $\mathrm{BC}$ possesses large cation exchange capacities on themselves, and oxidation of surface functional groups on BC can also increase CEC in the amended sediments (Liu et al., 2018b). The TOC in all treated groups was higher than that in the control because of external organic carbon input from immobilization materials, and TOC peaked in the $8 \mathrm{nB}$ treatment. Similarly, the $\mathrm{DOC}$ in the treated groups was also enhanced due to the addition of $\mathrm{BC}$ and $\mathrm{nZVI} / \mathrm{BC}$. As the most active type of organic carbon and the most likely to be utilized by microorganisms (Xu et al., 2019a), DOC increase after remediation was beneficial for the growth of microorganisms in sediments.

\subsection{Cd variations in overlying water and porewater}

The major purpose of heavy metal remediation in sediment is to reduce their release to overlying water. Fig. 3I shows the Cd concentrations in the overlying water of the sediments under different immobilization treatments at various times. Overall, Cd in overlying waters increased with time during the immobilization process. Notably, $\mathrm{Cd}$ in the control was higher than those in the treated groups, suggesting that $\mathrm{Cd}$ release was inhibited with $\mathrm{BC}$ or $\mathrm{nZVI} / \mathrm{BC}$ addition. After remediation, the average Cd concentrations $(\mu \mathrm{g} / \mathrm{L})$ in the overlying water displayed a decreasing trend: $C$ (control, 8.54) $>2 \mathrm{~B}(5.81)>5 \mathrm{~B}(4.61)>2 \mathrm{nB}(3.42)>8 \mathrm{~B}(3.27)>5 \mathrm{nB}$ (2.94) $>8 \mathrm{nB}$ (2.42). Compared to the control, the Cd in the overlying water decreased by about $69 \%, 63 \%, 60 \%, 58 \%, 44 \%$, and $31 \%$, respectively. The released $\mathrm{Cd}$ was mainly in the water-soluble fraction, which could be easily fixed through cation exchange, complexation, and adsorption (Liu et al., 2020b). The pH and CEC in treated sediments were changed after immobilization (Fig. 2), and
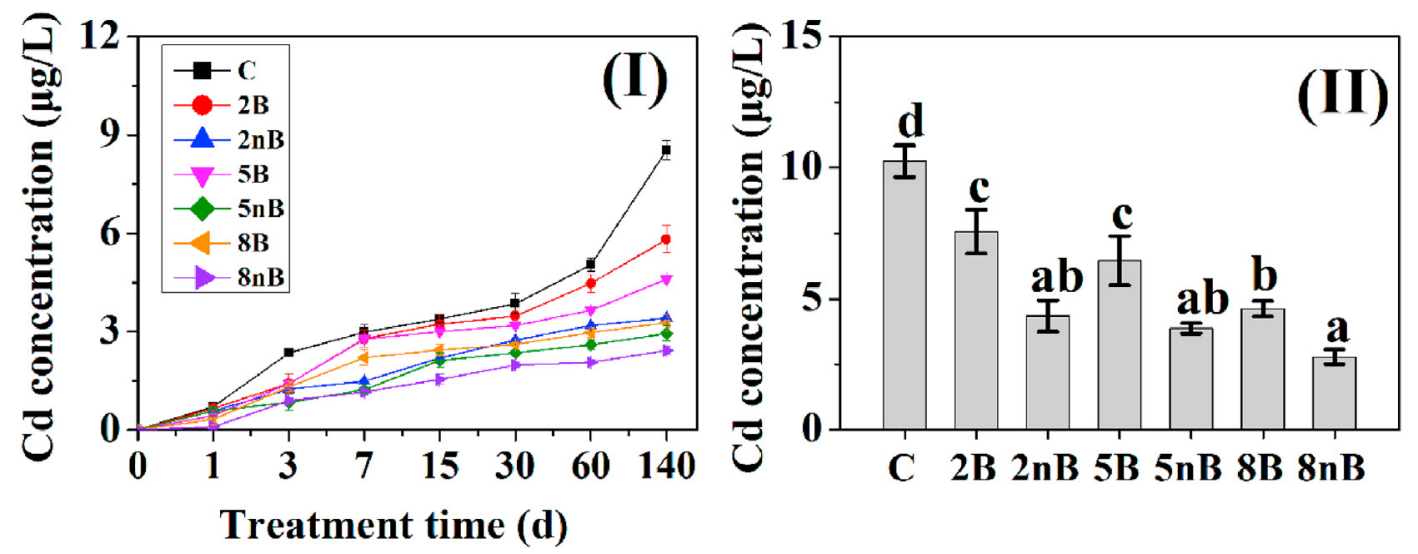

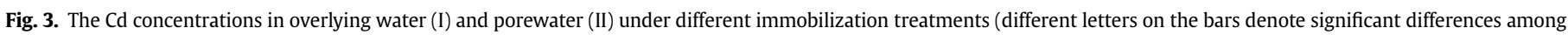
groups $(P<0.05))$. 
ion exchange for $\mathrm{Cd}^{2+}$ was promoted. Additionally, oxygencontaining functional groups and the large specific surface area of $\mathrm{BC}$ and $\mathrm{nZVI} / \mathrm{BC}$ also favored the stabilization of $\mathrm{Cd}$ via complexation and adsorption effects, respectively (Liu et al., 2018b). The decreasing rate of $\mathrm{Cd}$ release in the $\mathrm{BC}$ treated samples compared to the control was in the following order: $8 \mathrm{~B}>5 \mathrm{~B}>2 \mathrm{~B}$, presenting dose-dependent behavior, and a similar phenomenon was also observed for $\mathrm{nZVI} / \mathrm{BC}$. This could be explained by the substantially larger dosage of $\mathrm{BC}$ or $\mathrm{nZVI} / \mathrm{BC}$ supplying more adsorption sites and oxygen-containing functional groups. Specifically, the decreasing rates of $8 \mathrm{nB}, 5 \mathrm{nB}$, and $2 \mathrm{nB}$ were approximately 14\%,30\%, and $46 \%$ higher than $2 \mathrm{~B}, 5 \mathrm{~B}$, and $8 \mathrm{~B}$, respectively, indicating that the presence of nZVI enhanced the inhibiting effect of BC. This was because nZVI can also fix $\mathrm{Cd}^{2+}$ by electrostatic interaction, coprecipitation, and surface complexation (Mu et al., 2017). Additionally, the $\mathrm{pH}$ of the sediment increased after $\mathrm{nZVI} / \mathrm{BC}$ treatment (Fig. 2I), and the nZVI surface has much negative charges in a higher $\mathrm{pH}$ environment, thus reinforcing stronger electrostatic affinity with $\mathrm{Cd}^{2+}($ Xue et al., 2018a).

Porewater acts as a bridge of heavy metal release between sediments and overlying water; thus, $\mathrm{Cd}$ in overlying water is closely related to porewater (Ji et al., 2018). Therefore, the Cd concentrations in porewater after remediation were measured (Fig. 3II). The Cd concentrations in porewater were significantly reduced after remediation compared to the control $(P<0.05)$, indicating that $\mathrm{BC}$ and $\mathrm{nZVI} / \mathrm{BC}$ restricted $\mathrm{Cd}$ release from sediments to porewater. The reduction of $\mathrm{Cd}$ concentrations in the $2 \mathrm{~B}$, $2 \mathrm{nB}, 5 \mathrm{~B}, 5 \mathrm{nB}, 8 \mathrm{~B}$, and $8 \mathrm{nB}$ treated samples reached 26\%, 58\%, 37\%, $62 \%, 55 \%$, and $73 \%$, respectively. Overall, the Cd concentrations in porewater were close to those in overlying water. The Cd concentrations $(\mu \mathrm{g} / \mathrm{L})$ in porewater in treated groups followed the order of $2 \mathrm{~B}(7.56)>5 \mathrm{~B}(6.44)>8 \mathrm{~B}(4.62)>2 \mathrm{nB}(4.34)>5 \mathrm{nB}(3.88)>8 \mathrm{nB}$ (2.79). Similar to overlying water, the inhibiting effects of $B C$ and $\mathrm{nZVI} / \mathrm{BC}$ in porewater also showed a dose-dependent phenomenon. Moreover, the presence of nZVI promoted the inhibiting effects on $\mathrm{Cd}$ release from sediments to porewater, and the inhibiting effects of $2 \mathrm{nB}, 5 \mathrm{nB}$, and $8 \mathrm{nB}$ were 31\%, 25\%, and $18 \%$ higher than $2 \mathrm{~B}, 5 \mathrm{~B}$, and $8 \mathrm{~B}$, respectively.

\subsection{Variations in Cd mobility in sediments}

In situ immobilization can change the mobility of heavy metals by altering the fractions of heavy metals in sediments. Therefore, the effect of in situ immobilization can be further reflected by fraction analysis. Based on the BCR sequential extraction procedure, $\mathrm{Cd}$ in the sediment was classified into four fractions: acid fraction (F1), reducible fraction (F2), oxidizable fraction (F3), and residual fraction (F4), with an order of mobility F1 > F2 > F3 > F4 (Liu et al., 2018a). Generally, F4 is the most stable fraction under natural conditions; F1 is most readily mobilized for aquatic organisms; and F2 and F3 are considered to have potential toxicity because they would be released with redox condition changes (Li et al., 2019).

As shown in Fig. 4I, the $\mathrm{Cd}$ in the control was dominated by F1 and F2 ( 70\% and $25 \%$ of total, respectively), followed by F3 (4\%) and F4 (1\%). Great decreases in F1 were observed in all treated groups after immobilization. The proportion of $\mathrm{F} 1$ shifted from initial $70 \%-$ $65 \%, 60 \%, 63 \%, 57 \%, 62 \%$, and $54 \%$ for $2 \mathrm{~B}, 2 \mathrm{nB}, 5 \mathrm{~B}, 5 \mathrm{nB}, 8 \mathrm{~B}$, and $8 \mathrm{nB}$, respectively. Conversely, the proportions of F2, F3, and F4 increased by $8-30 \%, 44-139 \%$, and $50-201 \%$, respectively. The reason could be that $\mathrm{Cd}$ in $\mathrm{F} 1$ was associated with oxygen-containing functional groups of BC and nZVI/BC by complexation (Cui et al., 2019). In addition, F1 can be fixed to form stable inorganic forms (such as metal-phosphate or metal-silicate) through combination with the mineral and crystal lattices of BC (Xu et al., 2019). These effects were responsible for the reduction in $\mathrm{F} 1$ and the increase in the other three fractions. Decreased rates of F1 in $2 \mathrm{nB}, 5 \mathrm{nB}$, and $8 \mathrm{nB}$ were $126 \%, 94 \%$, and $85 \%$ higher than those in $2 \mathrm{~B}, 5 \mathrm{~B}$, and $8 \mathrm{~B}$, respectively. Simultaneously, increasing rates of F2 and F4 in nZVI/ $\mathrm{BC}$ treatments were higher than those in $\mathrm{BC}$, with increases of $111-274 \%$ and $41-242 \%$, respectively. This result indicated that $\mathrm{nZVI} / \mathrm{BC}$ was more effective than $\mathrm{BC}$ in immobilizing $\mathrm{Cd}$. This may be due to the association of iron oxides in nZVI/BC with $\mathrm{F} 1 \mathrm{Cd}$ through mineral-integrated, surface-bound, and inner sphere adsorption, increasing $\mathrm{Cd}$ stabilization after immobilization (Randall et al., 1999). Specifically, Cd adsorption by iron oxyhydroxide minerals through inner sphere adsorption was quite stable (Randall et al., 1999), and spontaneous secondary iron oxide binds Cd previously adsorbed to the crystal structure, highly strengthening Cd stability (Cooper et al., 2006). The above processes would result in great increases in F4 and F2 in nZVI/BC treatments compared to $\mathrm{BC}$. The $\mathrm{F} 3$ contents between $\mathrm{nZVI} / \mathrm{BC}$ and $\mathrm{BC}$ with the same addition were close because the changes in $\mathrm{F} 3$ were mainly ascribed to the association of $\mathrm{Cd}$ and $\mathrm{BC}$. Notably, the decreasing rates of $\mathrm{F} 1$ and increasing rates of $\mathrm{F} 2+\mathrm{F} 3+\mathrm{F} 4$ were related to the addition doses, and the change rates increased with the increased addition.

TCLP was applied to evaluate the leaching toxicity and mobility of $\mathrm{Cd}$ in the sediment treated with different doses of BC and nZVI/ $\mathrm{BC}$ after immobilization, and the results are shown in Fig. S1 and 4II. Significant decreases in the TCLP-leachable Cd concentrations were found in all treated groups $(P<0.05)$ (Fig. S1). Compared to the control, the TCLP-leachable Cd concentrations decreased by $7 \%$, $12 \%, 14 \%, 24 \%, 18 \%$, and $30 \%$ for $2 \mathrm{~B}, 2 \mathrm{nB}, 5 \mathrm{~B}, 5 \mathrm{nB}, 8 \mathrm{~B}$, and $8 \mathrm{nB}$, respectively, corresponding to $7 \%, 12 \%, 13 \%, 24 \%, 19 \%$, and $29 \%$ immobilization efficiencies. In the same way $\mathrm{Cd}$ concentrations in the overlying water and porewater, the immobilization efficiencies of both $\mathrm{BC}$ and $\mathrm{nZVI} / \mathrm{BC}$ showed a dose-dependent effect, with the order of $8 \mathrm{~B}>5 \mathrm{~B}>2 \mathrm{~B}$ and $8 \mathrm{nB}>5 \mathrm{nB}>2 \mathrm{nB}$, respectively. In addition, the presence of $\mathrm{nZVI}$ also promoted the immobilization efficiencies of BC, which indicated that nZVI could effectively immobilize Cd. Particularly, the TCLP-leachable Cd concentrations in the control and 2B treatments were 1.09 and $1.01 \mathrm{mg} / \mathrm{L}$, respectively, which were slightly higher than the concentration of US EPA regulation ( $1 \mathrm{mg} / \mathrm{L}$ ), posing potential damage to the ecosystem and human health (Li et al., 2019).

\subsection{Effects of $\mathrm{pH}$ on $\mathrm{Cd}$ in overlying water and porewater}

$\mathrm{pH}$ is an important factor affecting the behavior and mobility of heavy metals in sediments, and the mobility may change with $\mathrm{pH}$ changes (Hong et al., 2011). In this study, the released Cd concentrations in the overlying water under different $\mathrm{pH}$ values increased with time during most of the entire immobilization process (Fig. 5). After $140 \mathrm{~d}$ of immobilization, the Cd in the overlying water in the control was higher than that in the treated groups at $\mathrm{pH}$ values of 3 , 5,7 and 9, suggesting that both $\mathrm{BC}$ and $\mathrm{nZVI} / \mathrm{BC}$ inhibited $\mathrm{Cd}$ release from sediments. Compared to $\mathrm{pH} 7$, the $\mathrm{Cd}$ in the overlying water in the control at $\mathrm{pH} 3$ and 5 increased by about 6 and 4 times, respectively, while the pH 9 treatment decreased by 30\%. This demonstrated that low $\mathrm{pH}$ enhanced the release of $\mathrm{Cd}$ from sediments to overlying water. The reason was mainly because (1) abundant $\mathrm{H}^{+}$can compete with metal ions for the sediment colloid, leading to Cd release; and (2) lower $\mathrm{pH}$ can favor the dissolution of original Cd precipitation (e.g., $\mathrm{Cd}\left(\mathrm{CdCO}_{3}\right)$ ) in sediment (Xue et al., $2018 \mathrm{~b})$. For the $\mathrm{BC}$ treatment, the $\mathrm{Cd}$ concentrations $(\mu \mathrm{g} / \mathrm{L})$ at different $\mathrm{pH}$ values showed great differences, with a decreasing order of pH 3 (30.82) > pH 5 (16.19) > pH 7 (5.30) > pH 9 (3.30), indicating that the immobilization capacity of $\mathrm{BC}$ weakened with the $\mathrm{pH}$ decrease. This could be explained by the fact that many $\mathrm{H}^{+}$ ions can compete with metal ions for the active functional groups 

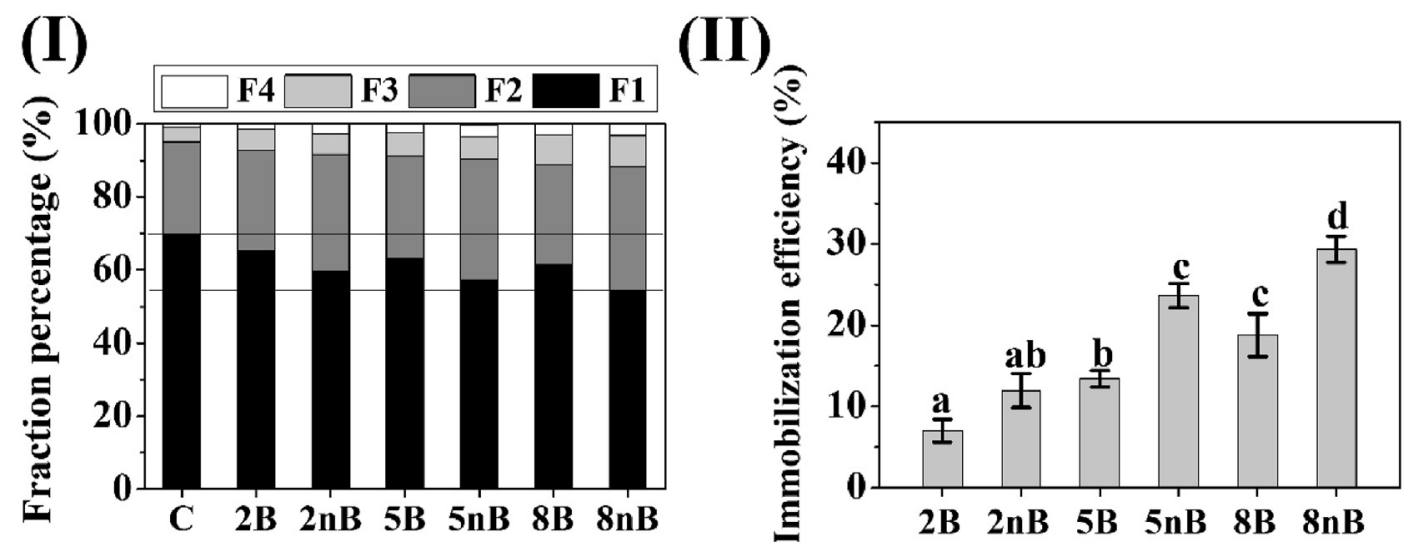

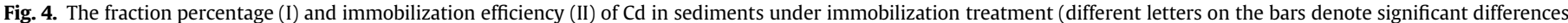
among groups $(P<0.05))$.
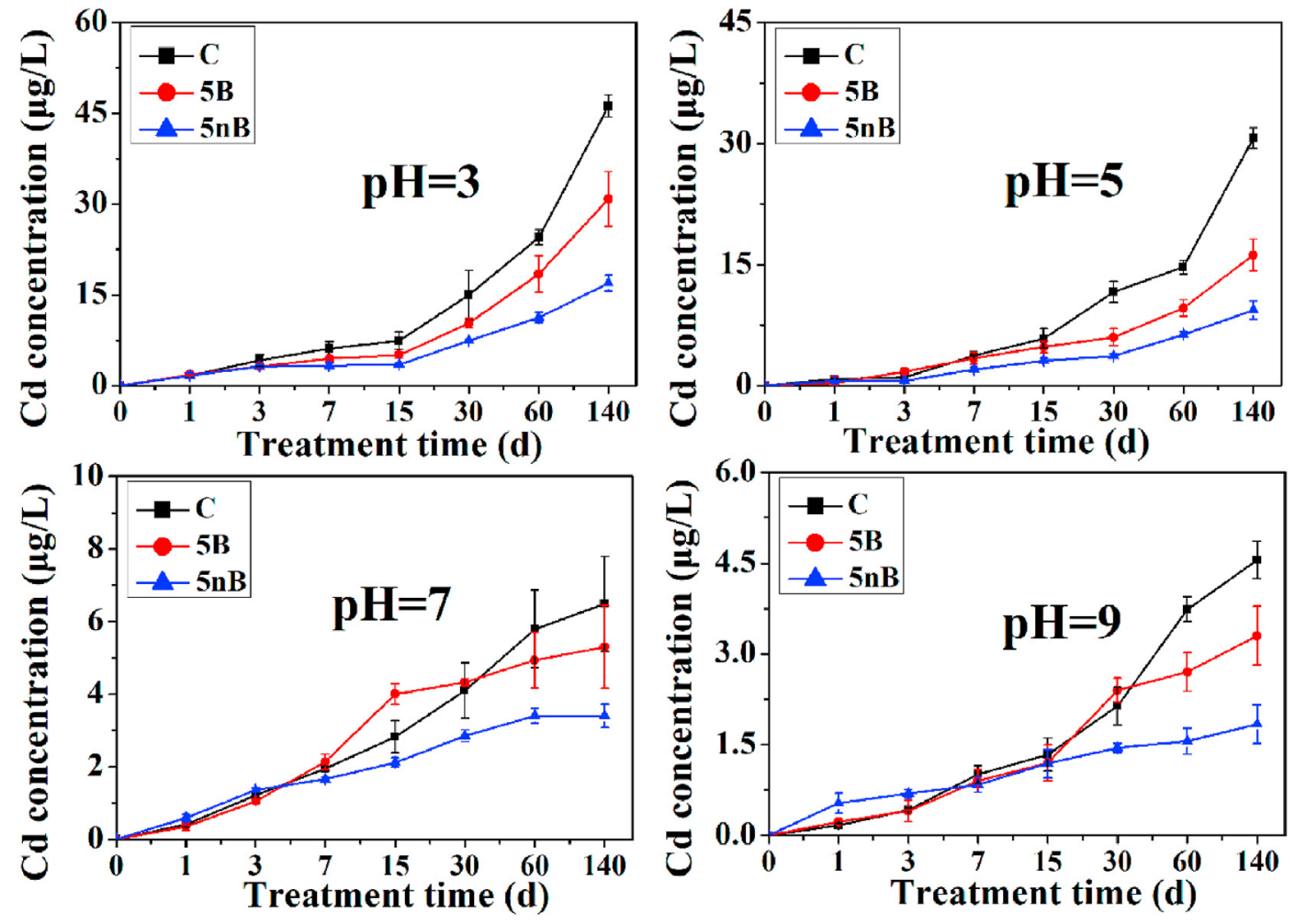

Fig. 5. Cd variations in overlying water under different $\mathrm{pH}$ with treatment time.

on the $\mathrm{BC}$ surface at lower $\mathrm{pH}$, which reduces the adsorption of $\mathrm{Cd}^{2+}$ and immobilization capacity of BC (Zhang et al., 2017). Interestingly, the released $\mathrm{Cd}$ concentrations in the treated groups were slightly higher than those in the control in the early stage at $\mathrm{pH} 7$ and 9. This may be related to the decomposition of organic matter by microorganisms, resulting in the release of $\mathrm{Cd}$ associated with organic matter. However, the detailed reason for this phenomenon needs to be explored in future studies.

Notably, nZVI/BC was more effective in immobilizing Cd than BC at lower $\mathrm{pH}$ values. In $\mathrm{pH} 3$ remediation, the $\mathrm{Cd}$ in overlying water treated by BC decreased by $33 \%$ compared to the control, while the overlaying water in the $\mathrm{nZVI} / \mathrm{BC}$ treated sample was $45 \%$. This was attributed to that $\mathrm{nZVI}$ of $\mathrm{nZVI} / \mathrm{BC}$ oxidization causing $\mathrm{OH}^{-}$release, resulting in the $\mathrm{pH}$ increase (from 7.60 to 8.24 , Fig. 2I), which could partly counteract the interference of external $\mathrm{H}^{+}$input (Xue et al., 2018b). Subsequently, an increase in sediment $\mathrm{pH}$ weakened the competition of $\mathrm{H}^{+}$with $\mathrm{Cd}^{2+}$ for $\mathrm{nZVI} / \mathrm{BC}$, favoring the stabilization of $\mathrm{Cd}^{2+}$ in sediments (Yuan et al., 2015). Under neutral and alkaline treatments ( $\mathrm{pH}=7$ and 9), nZVI/BC also exhibited higher inhibitory effects than $\mathrm{BC}$ upon $\mathrm{Cd}$ release. Moreover, the increasing trend of $\mathrm{Cd}$ in $\mathrm{nZVI} / \mathrm{BC}$ became smooth after $30 \mathrm{~d}$ compared to that in acidic conditions. This phenomenon was because more negative charges on the nZVI surface presented stronger electrostatic affinity toward $\mathrm{Cd}^{2+}$ at higher $\mathrm{pH}$, and the immobilization capacity of nZVI/BC was accordingly enhanced compared to BC (Liu et al., 2020a).

Fig. 6 illustrates the $C d$ variations in porewater under different $\mathrm{pH}$ values after immobilization. The Cd concentrations in the control at $\mathrm{pH} 3$ were $33 \%, 88 \%$, and $90 \%$ higher than those at $\mathrm{pH} 5,7$, and 

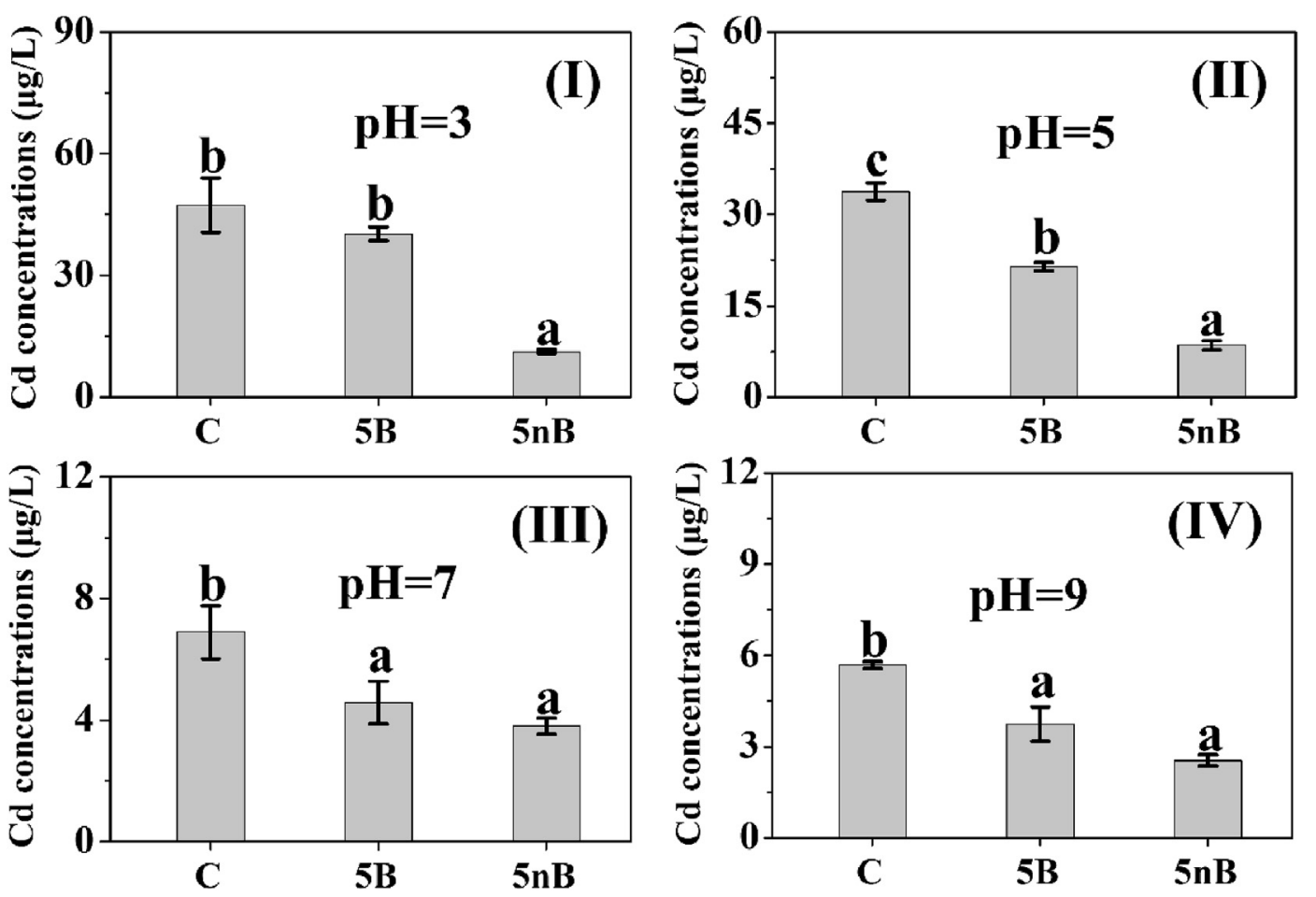

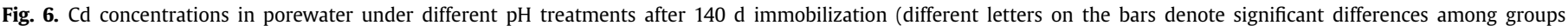
$(P<0.05))$.

9, respectively, indicating that $\mathrm{Cd}$ in porewater also showed an increasing trend with $\mathrm{pH}$ decrease. Except for $\mathrm{pH} 3$, Cd concentrations in the treated groups were all significantly reduced compared to the control $(P<0.05)$. It suggested that $\mathrm{BC}$ and $\mathrm{nZVI} / \mathrm{BC}$ could significantly inhibit $C d$ release to porewater. Furthermore, $\mathrm{nZVI} / \mathrm{BC}$ presented a better performance than $\mathrm{BC}$ in restricting $\mathrm{Cd}$ release from sediments to porewater in this study. With the four different $\mathrm{pH}$ treatments, the $\mathrm{Cd}$ concentrations in the $\mathrm{nZVI} / \mathrm{BC}$ treatments were all lower than those in the $\mathrm{BC}$ treatments, and a significant reduction was even observed with the $\mathrm{pH} 3$ treatments $(P<0.05)$. Overall, both BC and nZVI/BC could prevent the release of $\mathrm{Cd}$ from sediments to overlying water and porewater, and nZVI/BC was more efficient at various $\mathrm{pH}$ values.

\subsection{Bacterial community variations}

\subsubsection{Richness and diversity of bacterial communities}

As shown in Table 2, a total of 438,129 effective tags and 4926 OTUs were obtained from 8 sediment treatments. The rarefaction curves finally tended to saturation (Fig. S2), demonstrating that the amount of sequencing data was reasonable. In this study, an abundance-based coverage estimator (ACE, Chao and Lee, 1992) and Shannon-Wiener index (Chen et al., 2017) were applied to assess the richness and diversity of the bacterial community in all sediments, respectively. According to ACE analysis, the richness of the bacterial community in most treatments was lower than that in the control except for $2 \mathrm{~B}$ and $5 \mathrm{~B}$. The enhancements in the diversity of the bacterial community after immobilization were only observed in the $2 \mathrm{~B}$ and $2 \mathrm{nB}$ treatments compared to the control. To explore the reason for the change in the bacterial community, CCA was performed to test the relationship among sediment properties and TCLP-Cd, as shown in Table S3. The results showed that the first two axes of the CCA explained $59.89 \%$ and $22.55 \%$ of the variance for bacteria between environmental factors and species data. The bacterial community was only significantly influenced by $\mathrm{pH}$ $(P<0.05)$. This result was consistent with the study of Huang et al. (2017), who confirmed that the addition of BC can affect the bacterial community by changing the $\mathrm{pH}$ of sediments. The $\mathrm{pH}$ can not only directly affect bacterial growth but also indirectly cause changes to the bacterial community structure by affecting heavy metal mobility and regulating nutrients (Zhao et al., 2019). Following remediation, the $\mathrm{pH}$ values in the treated groups all presented significant increases compared to the control except for the $2 \mathrm{nB}$ treatment (Fig. 2). A pH that is too high can restrain the

Table 2

Quality control, diversity and richness of bacterial community in sediments.

\begin{tabular}{|c|c|c|c|c|c|c|}
\hline Sample & Clean tags & Effective tags & OTUs & Q30 & ACE & Shannon-Wiener index \\
\hline $\mathrm{C}$ & 81,635 & 63,334 & 704 & 92.37 & 754.73 & 4.79 \\
\hline $2 \mathrm{~B}$ & 89,684 & 59,728 & 813 & 91.85 & 850.17 & 5.93 \\
\hline $2 \mathrm{nB}$ & 91,552 & 64,529 & 698 & 91.72 & 730.86 & 5.19 \\
\hline $5 B$ & 93,160 & 59,217 & 714 & 92.12 & 883.05 & 4.55 \\
\hline $5 \mathrm{nB}$ & 95,007 & 65,164 & 690 & 92.31 & 744.55 & 4.70 \\
\hline $8 B$ & 91,703 & 61,250 & 633 & 92.12 & 673.32 & 4.50 \\
\hline $8 \mathrm{nB}$ & 96,011 & 64,907 & 674 & 92.03 & 716.86 & 4.58 \\
\hline Total & & 438,129 & 4926 & & & \\
\hline
\end{tabular}




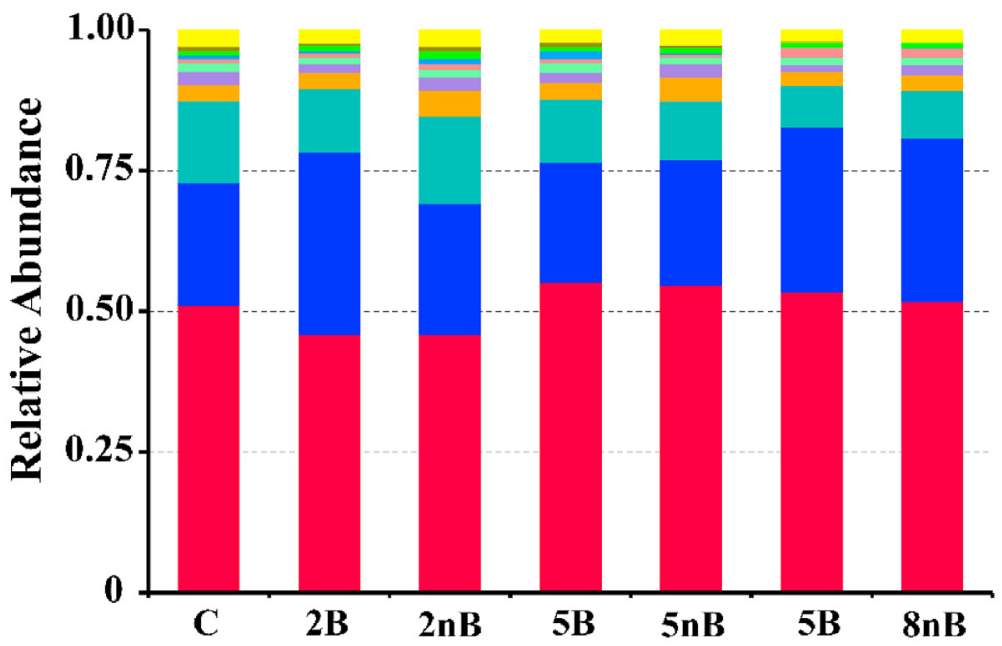

\section{(I)}

Others

Melainabacteria

Actinobacteria

Gemmatimonadetes

unidentified Bacteria

Chloroflexi

Planctomycetes

Tenericutes

Proteobacteria

- Firmicutes

Bacteroidetes

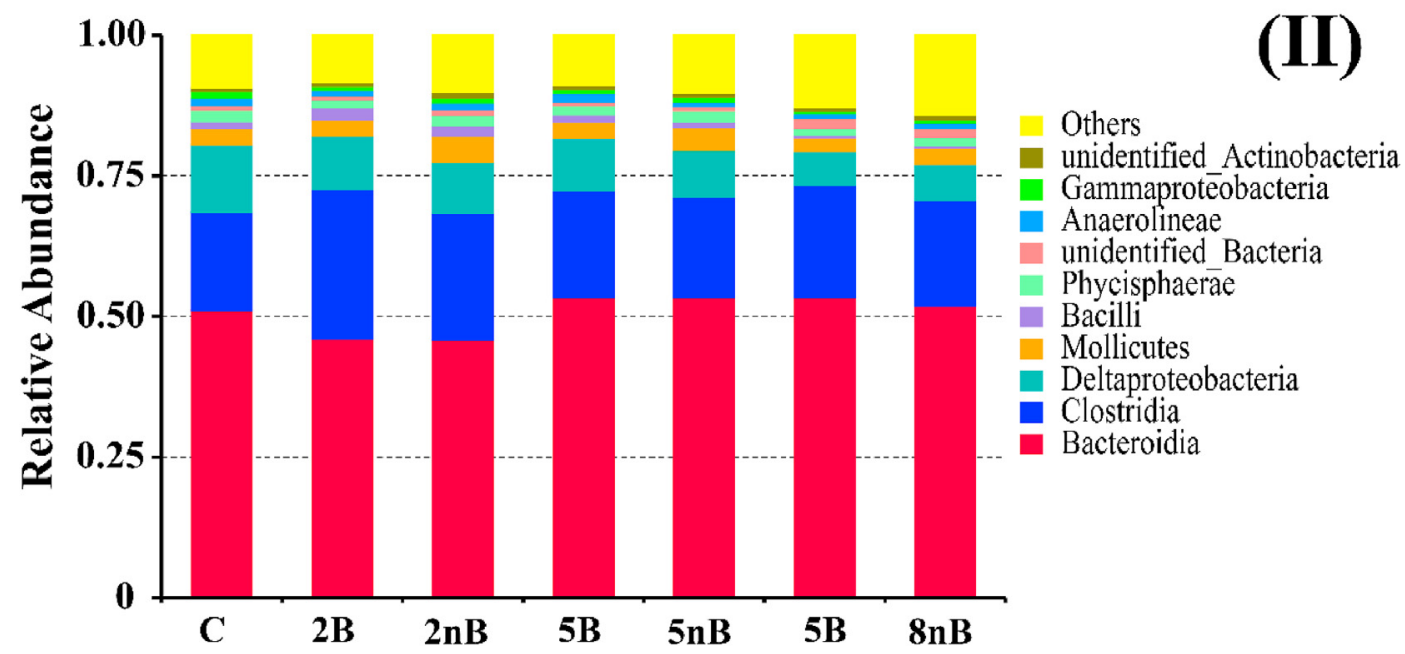

Fig. 7. The relative abundances of top 10 bacterial communities at levels of phylum (I), and class (II).

growth of some bacteria, thus decreasing the diversity and richness of the bacterial community (Huang et al., 2017).

Additionally, $\mathrm{BC}$ and $\mathrm{nZVI} / \mathrm{BC}$ can also directly affect the change in the bacterial community during immobilization. Usually, the appropriate addition of BC can alter the carbon cycle of sediments, which generates a positive impact on bacterial growth (Liu et al., 2020a). However, some harmful substances (such as polycyclic aromatic hydrocarbons, benzene, and radicals) were produced and then combined with BC during its production (Liao et al., 2014). Therefore, excessive application of BC to sediments can also pose some adverse effects to the bacterial community, and this also explained why both richness and diversity of the bacterial community in the $8 \mathrm{~B}$ treatment were inhibited. Notably, the richness of the bacterial community in the $2 \mathrm{nB}$ and $5 \mathrm{nB}$ treatments was restrained compared to the control, while the same doses of $\mathrm{BC}$ treatments were not inhibited. The reason for this may be the toxicity of nZVI exerted on organisms via oxidative damage and the release of excess iron ions (Cai et al., 2019). Overall, although the addition of more BC and $\mathrm{nZVI} / \mathrm{BC}$ enhanced the immobilization of $\mathrm{Cd}$ in sediments, they can pose some negative effects on the bacterial community of sediment due to their own toxicities.

\subsubsection{Changes in the composition of the bacterial community}

The relative abundances of bacterial 16S rRNA genes at the phylum, class, and genus levels were determined to analyze the composition of bacterial communities. As presented in Fig. 7I, the dominant bacterial phyla in the control were Bacteroidetes, Firmicutes, and Proteobacteria, constituting approximately 51\%, 22\%, and $15 \%$ of the total bacterial community, respectively. This result was consistent with the study of Liu et al. (2020a), who found that Cdpolluted sediments were also dominated by the above three bacterial phyla. In addition, a sum of the relative abundances of Tenericutes, Planctomycetes, Chloroflexi, Gemmatimonadetes, Actinobacteria, and Melainabacteria occupied 9\% of the total community. After immobilization, the composition of bacterial communities at the phylum level in the treated groups showed some changes. The relative abundances of Firmicutes in all treated groups were increased by $1-49 \%$. Firmicutes carries multifarious resistant genes of heavy metals, which can favor their rapid propagation in heavy metal-contaminated environments (Guo et al., 2019). The relative abundances of Bacteroidetes in most treatments all presented slight increases (1-8\%) compared to the control. Bacteroidetes can secrete sphingolipids to protect cell surfaces and functions from various adverse stresses, which ensures its better survival in heavy metal-polluted environments (Rickard et al., 2004). Particularly, the 2B and 2 nB treatments decreased by $10.18 \%$ and $10.29 \%$, respectively, which was probably due to competition for nutrients with rapid-growing Firmicutes. In 


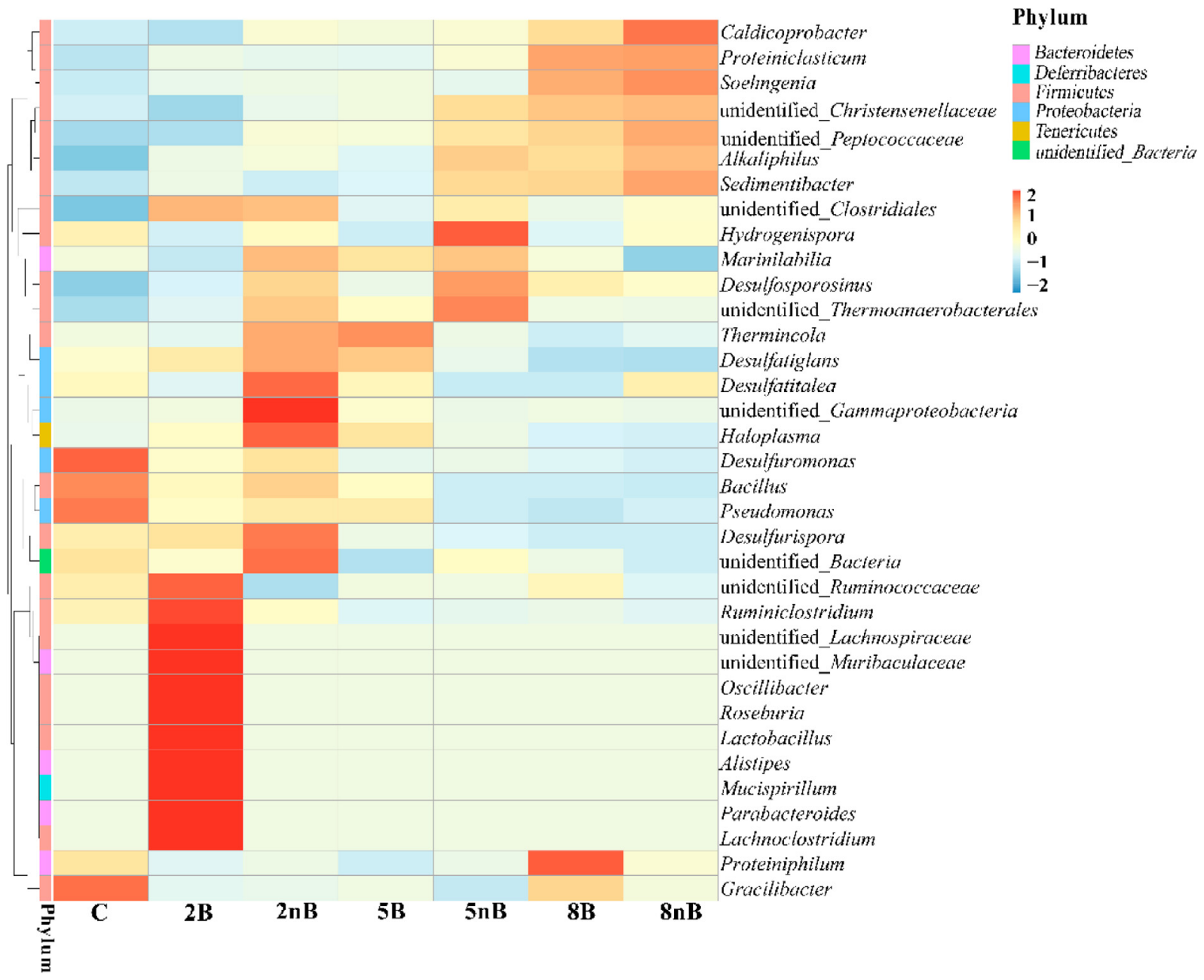

Fig. 8. Hierarchically clustered heatmap analysis of highly represented bacterial taxa at genera level (top 35).

addition to the improvement of carbon sources, many carriers of immobilization materials also enhanced the growth of Firmicutes and Bacteroidetes (Liu et al., 2020a). Notably, the relative abundance of Proteobacteria in the treated groups exhibited some declines (by 6-50\%). Proteobacteria is one of the dominant bacteria in heavy metal-contaminated sediment and is proven to be related to the removal of pollutants (Zhao et al., 2019). Therefore, the reduction in bioavailability and mobility of $\mathrm{Cd}$ in the treated sediments was reduced after remediation. In Fig 7II, Bacteroidia, Clostridia, and Deltaproteobacteria were the three predominant bacterial classes in the control, which accounted for $51 \%, 17 \%$, and $12 \%$ of the total bacterial community, respectively. After remediation, the relative abundance of Clostridia increased by $7-52 \%$, while a noticeable decrease of $21-50 \%$ was observed in Deltaproteobacteria. For Bacteroidia, its relative abundance in most treated groups exhibited some increases, while $2 \mathrm{~B}$ and $2 \mathrm{nB}$ treatments presented some decreases compared to the control (all decreased by $10 \%$ ). This phenomenon was similar to the abundance change of Bacteroidetes, which competed with rapid-growing Clostridia. In addition, both Clostridia and Bacteroidia all participated in organic matter degradation and organic acid production (Yang et al., 2016), suggesting that the consumption of organic matter was accelerated in sediments after immobilization.

Fig. 8 shows the clustered heatmap analysis of the bacterial community at the genus level. Gracilibacter, Pseudomonas, Bacillus, and Desulfuromonas were the most dominant genera in the control.
After remediation, noticeable shifts of the dominant genera occurred in all treated groups compared to those in the control. For example, with the addition of $2 \% \mathrm{BC}$, unidentified Ruminococcaceae, Ruminiclostridium, unidentified Lachnospiraceae, unidentified Muribaculaceae, Oscillibacter, Roseburia, Lactobacillus, Alistipes, Mucispirillum, Parabacteroides, and Lachnoclostridium became the primary genera. This result was confirmed by the study of Liu et al. (2020a), indicating that the composition of bacterial communities was very susceptible to the addition of immobilization materials at the genus level. Unlike the phylum level, the dominant genera of bacterial communities in the $\mathrm{BC}$ treatments were greatly different from those in the nZVI/BC treatments, indicating that nZVI application also produced tremendous effects on bacterial communities at the genera level. Especially, the relative abundance of bacteria in the $2 \mathrm{~B}$ treatment was higher than that in the other treatments, which can be proven by the Shannon-Wiener index (Table 2). Sulfate reducing bacteria (SRB) can promote the stabilization of heavy metals in sediments through the formation of metal sulfides (Peng et al., 2020); moreover, the relative abundance of SRB in sediments was enhanced after immobilization according to a previous study (Xue et al., 2018b). However, in this study, the relative abundances of dominant SRB, e.g., Desulfatitalea, Desulfuromonas, and Desulfurispora, exhibited some declines in most treated groups compared to the control. For example, Desulfuromonas decreased by about $61 \%, 38 \%, 76 \%, 73 \%, 81 \%$, and $85 \%$ in the $2 \mathrm{~B}, 2 \mathrm{nB}, 5 \mathrm{~B}, 5 \mathrm{nB}$, $8 \mathrm{~B}$, and $8 \mathrm{nB}$ treatments, respectively. This indicated that the 
application of $\mathrm{BC}$ or $\mathrm{nZVI} / \mathrm{BC}$ would disturb the reduction of sulfate, which was not conducive to the stabilization of $\mathrm{Cd}$. As mentioned above, BC could contain many oxidative free radicals, which inhibited the growth of SRB, thus decreasing the relative abundances in SRB. Additionally, higher $\mathrm{pH}$ can also restrain the growth of SRB, and it can be partly responsible for the decrease of SRB (Yan et al., 2018). Interestingly, some increases were also observed in Desulfatitalea at $2 \mathrm{nB}$ (increased by 12\%), Desulfurispora at 2B and $2 \mathrm{nB}$ (increased by $12 \%$ and 52\%, respectively), and Desulfatiglans at 2B, $2 \mathrm{nB}$, and 5B (increased by $40 \%, 92 \%$, and 72\%, respectively). It can be found that the increases in these SRBs mostly occurred in the lower dose treatments of immobilization materials, and these SRBs in the higher dose treatments were inhibited. Therefore, applying appropriate $\mathrm{BC}$ and $\mathrm{nZVI} / \mathrm{BC}$ can still promote the relative abundance of some SRB in sediments.

\section{Conclusions}

In this study, $\mathrm{BC}$ and $\mathrm{nZVI} / \mathrm{BC}$ at different doses were employed to immobilize $C d$ in sediments in situ. The results showed that the addition of BC and nZVI/BC distinctly inhibited Cd mobility and bioavailability in sediments. Based on the remediation effect of $\mathrm{Cd}$, $8 \%$ by mass of the added dose of $\mathrm{BC}$ or $\mathrm{nZVI} / \mathrm{BC}$ was considered as the best. Both $\mathrm{BC}$ and $\mathrm{nZVI} / \mathrm{BC}$ in an alkaline environment $(\mathrm{pH}=9)$ showed the highest remediation efficiency, which indicates that an alkaline environment was proven to be optimal for the in-situ immobilization of sediment. Notably, the presence of nZVI in BC greatly favored $\mathrm{Cd}$ immobilization in sediments. The nZVI/BC exhibited better performance than raw $\mathrm{BC}$ in inhibiting $\mathrm{Cd}$ release from sediment to the water environment under various $\mathrm{pH}$ conditions. Following immobilization, the richness and diversity of bacterial communities at low doses of treatments were enhanced, while inhibition was observed in high dose treatments, which was due to the changes in $\mathrm{pH}$ in sediments and toxicity of remediation materials. In addition, some changes in relative abundances occurred for the dominant species of the bacterial community in the sediments at the genus, phylum, and class levels. Especially, although higher concentrations of $\mathrm{BC}$ or $\mathrm{nZVI} / \mathrm{BC}$ greatly reduced $\mathrm{Cd}$ mobility, the excessive application of $\mathrm{BC}$ and $\mathrm{nZVI} / \mathrm{BC}$ could damage the bacterial community. Therefore, comprehensive consideration should be given to the remediation efficiency and ecological impact when Cd-contaminated sediment is immobilized in-situ using BC and $\mathrm{nZVI} / \mathrm{BC}$.

\section{CRediT authorship contribution statement}

Qunqun Liu: Investigation, Conceptualization, Writing - original draft, Writing - review \& editing, Data curation, Formal analysis, Methodology. Yanqing Sheng: Methodology, Supervision, Project administration, Resources, Writing - review \& editing. Wenjing Wang: Methodology, Data curation, Writing - review \& editing. Xiaozhu Liu: Investigation, Methodology.

\section{Declaration of competing interest}

The authors declare that they have no known competing financial interests or personal relationships that could have appeared to influence the work reported in this paper.

\section{Acknowledgements}

This work was supported by the Strategic Priority Research Program of the Chinese Academy of Sciences (CAS) (Grant No. XDA23050203). Additional support was provided by the Regional Key Project of STS of CAS (Grant No. KFJ-STS-QYZX-057), and the
Key Research and Development Program of Shandong Province (Grant No. 2019GSF109002).

\section{Appendix A. Supplementary data}

Supplementary data to this article can be found online at https://doi.org/10.1016/j.jclepro.2020.125076.

\section{References}

Beiyuan, J., Tsang, D.C.W., Valix, M., Zhang, W., Yang, X., Ok, Y.S., Li, X.D., 2017. Selective dissolution followed by EDDS washing of an e-waste contaminated soil: extraction efficiency, fate of residual metals, and impact on soil quality. Chemosphere 166, 489-496.

Cai, C., Zhao, M., Yu, Z., Rong, H., Zhang, C., 2019. Utilization of nanomaterials for insitu remediation of heavy metal (loid) contaminated sediments: a review. Sci. Total Environ. 662, 205-217.

Chao, A., Lee, S.M., 1992. Estimating the number of classes via sample coverage. J. Am. Stat. Assoc. 87, 210-217.

Chen, Y., Liu, Y., Li, Y., Wu, Y., Chen, Y., Zeng, G., Zhang, J., Li, H., 2017. Influence of biochar on heavy metals and microbial community during composting of river sediment with agricultural wastes. Bioresour. Technol. 243, 347-355.

Cui, L., Noerpel, M.R., Scheckel, K.G., Ippolito, J.A., 2019. Wheat straw biochar reduces environmental cadmium bioavailability. Environ. Int. 126, 69-75.

Cooper, D.C., Picardal, F.F., Coby, A.J., 2006. Interactions between microbial iron reduction and metal geochemistry: effect of redox cycling on transition metal speciation in iron bearing sediments. Environ. Sci. Technol. 40, 1884-1891.

Guo, Q., Li, N., Xie, S., 2019. Heavy metal spill influences bacterial communities in freshwater sediments. Arch. Microbiol. 201, 847-854.

Huang, D., Liu, L., Zeng, G., Xu, P., Huang, C., Deng, L., Wang, R., Wan, J., 2017. The effects of rice straw biochar on indigenous microbial community and enzymes activity in heavy metal-contaminated sediment. Chemosphere 174, 545-553.

Huang, D., Xue, W., Zeng, G., Wan, J., Chen, G., Huang, C., Zhang, C., Cheng, M., Xu, P., 2016. Immobilization of $\mathrm{Cd}$ in river sediments by sodium alginate modified nanoscale zero-valent iron: impact on enzyme activities and microbial community diversity. Water Res. 106, 15-25.

Hong, Y.S., Kinney, K.A., Reible, D.D., 2011. Effects of cyclic changes in pH and salinity on metals release from sediments. Environ. Toxicol. Chem. 30, 1775-1784.

Ji, H., Li, H., Zhang, Y., Ding, H., Gao, Y., Xing, Y., 2018. Distribution and risk assessment of heavy metals in overlying water, porewater, and sediments of Yongding River in a coal mine brownfield. J. Soils Sediments 18, 624-639.

Liao, S., Pan, B., Li, H., Zhang, D., Xing, B., 2014. Detecting free radicals in biochars and determining their ability to inhibit the germination and growth of corn, wheat and rice seedlings. Environ. Sci. Technol. 48, 8581-8587.

Li, F., Chen, J., Hu, X., He, F., Bean, E.Z., Tsang, D.C., Ok, Y.S., Gao, B., 2020a. Applications of carbonaceous adsorbents in the remediation of polycyclic aromatic hydrocarbon-contaminated sediments: a review. J. Clean. Prod. 255, 120263.

Li, Y., Zimmerman, A.R., He, F., Chen, J., Han, L., Chen, H., Han, L., Chen, H., Gao, B., 2020b. Solvent-free synthesis of magnetic biochar and activated carbon through ball-mill extrusion with $\mathrm{Fe}_{3} \mathrm{O}_{4}$ nanoparticles for enhancing adsorption of methylene blue. Sci. Total Environ., 137972

Liu, Q., Sheng, Y., Wang, W., Li, C., Zhao, G., 2020a. Remediation and its biological responses of $\mathrm{Cd}$ contaminated sediments using biochar and minerals with nanoscale zero-valent iron loading. Sci. Total Environ. 136650.

Liu, Q., Sheng, Y., Jiang, M., Zhao, G., Li, C., 2020b. Attempt of basin-scale sediment quality standard establishment for heavy metals in coastal rivers. Chemosphere 125596.

Liu, O., Wang, F., Meng, F., Jiang, L., Li, G., Zhou, R., 2018a. Assessment of metal contamination in estuarine surface sediments from Dongying City, China: use of a modified ecological risk index. Mar. Pollut. Bull. 126, 293-303.

Liu, S.J., Liu, Y.G., Tan, X.F., Zeng, G.M., Zhou, Y.H., Liu, S.B., Yin, Z.H., Jiang, L.H., Li, M.F., Wen, J., 2018b. The effect of several activated biochars on Cd immobilization and microbial community composition during in-situ remediation of heavy metal contaminated sediment. Chemosphere 208, 655-664.

Li, X., Yang, Z., Zhang, C., Wei, J., Zhang, H., Li, Z., Ma, C., Wang, M., Chen, J., Hu, J. 2019. Effects of different crystalline iron oxides on immobilization and bioavailability of Cd in contaminated sediment. Chem. Eng. J. 373, 307-317.

Luo, H., Lin, Q., Zhang, X., Huang, Z., Liu, S., Jiang, J., Xiao, R., Liao, X., 2019. New insights into the formation and transformation of active species in $\mathrm{nZVI} / \mathrm{BC}$ activated persulfate in alkaline solutions. Chem. Eng. J. 359, 1215-1223.

Ministry of Ecology and Environment of the People's Republic of China (MEPC), 2017. Soil Quality-Determination of Cation Exchange Capacity- Hexamminecobalt Trichloride Solution-Spectrophotometric Method. China Environmental Press, Beijing, China (In Chinese).

Mu, Y., Jia, F., Ai, Z., Zhang, L., 2017. Iron oxide shell mediated environmental remediation properties of nano zero-valent iron. Environ. Sci. Nano 4, 27-45.

Peng, W., Li, X., Lin, M., Fan, W., 2020. Microbiological analysis of cadmiumcontaminated sediments during biostabilization with indigenous sulfatereducing bacteria. J. Soils Sediments 20, 584-593.

Randall, S.R., Sherman, D.M., Ragnarsdottir, K.V., Collins, C.R., 1999. The mechanism of cadmium surface complexation on iron oxyhydroxide minerals. Geochem. Cosmochim. Acta 63, 2971-2987. 
Rickard, A.H., McBain, A.J., Stead, A.T., Gilbert, P., 2004. Effects of fluid shear force upon the diversity and species interactions within freshwater biofilms. Appl. Environ. Microbiol. 70, 7426-7435.

Song, B., Zeng, G., Gong, J., Liang, J., Xu, P., Liu, Z., Zhang, Y., Zhang, C., Cheng, M., Liu, Y., Ye, S., Yi, H., Ren, X., 2017. Evaluation methods for assessing effectiveness of in situ remediation of soil and sediment contaminated with organic pollutants and heavy metals. Environ. Int. 105, 43-55.

Sun, Y., Iris, K.M., Tsang, D.C., Cao, X., Lin, D., Wang, L., Graham, N.j., Alessi, D.S., Komárek, M., Ok, Y.S., Feng, Y., Li, X., 2019. Multifunctional iron-biochar composites for the removal of potentially toxic elements, inherent cations, and hetero-chloride from hydraulic fracturing wastewater. Environ. Int. 124, $521-532$.

Wang, L., Chen, S.S., Sun, Y., Tsang, D.C., Yip, A.C., Ding, S., Hou, D., Baek, K., Ok, Y.S., 2019. Efficacy and limitations of low-cost adsorbents for in-situ stabilisation of contaminated marine sediment. J. Clean. Prod. 212, 420-427.

Wang, L., Tsang, D.C.W., Poon, C.S., 2015. Green remediation and recycling of contaminated sediment by waste-incorporated stabilization/solidification. Chemosphere 122, 257-264.

Xue, W., Huang, D., Zeng, G., Wan, J., Zhang, C., Xu, R., Cheng, M., Deng, R., 2018a. Nanoscale zero-valent iron coated with rhamnolipid as an effective stabilizer for immobilization of $\mathrm{Cd}$ and $\mathrm{Pb}$ in river sediments. J. Hazard Mater. 341, $381-389$.

Xue, W., Peng, Z., Huang, D., Zeng, G., Wan, J., Xu, R., Cheng, R., Zhang, C., Jiang, D., Hu, Z., 2018b. Nanoremediation of cadmium contaminated river sediments: microbial response and organic carbon changes. J. Hazard Mater. 359, 290-299.

Xu, H., Zou, L., Guan, D., Li, W., Jiang, H., 2019a. Molecular weight-dependent spectral and metal binding properties of sediment dissolved organic matter from different origins. Sci. Total Environ. 665, 828-835.

Xu, Y., Qi, F., Bai, T., Yan, Y., Wu, C., An, Z., Luo, S., Huang, Z., Xie, P., 2019b. A further inquiry into co-pyrolysis of straws with manures for heavy metal immobilization in manure derived biochars. J. Hazard Mater. 380, 120870.

Yang, F., Zhang, S., Sun, Y., Cheng, K., Li, J., Tsang, D.C., 2018. Fabrication and characterization of hydrophilic corn stalk biochar-supported nanoscale zero-valent iron composites for efficient metal removal. Bioresour. Technol. 265, 490-497.

Yang, Z.H., Xu, R., Zheng, Y., Chen, T., Zhao, L.J., Li, M., 2016. Characterization of extracellular polymeric substances and microbial diversity in anaerobic codigestion reactor treated sewage sludge with fat. oil, grease. Bioresour. Technol. 212, 164-173.

Yang, X., Tsibart, A., Nam, H., Hur, J., El-Naggar, A., Tack, F.M., Wang, C., Lee, Y, Tsang, D., Ok, Y.S., 2019. Effect of gasification biochar application on soil quality: trace metal behavior, microbial community, and soil dissolved organic matter J. Hazard Mater. 365, 684-694.

Yan, L., Ye, J., Zhang, P., Xu, D., Wu, Y., Liu, J., Zhang, H., Fang, W., Wang, B., Zeng, G., 2018. Hydrogen sulfide formation control and microbial competition in batch anaerobic digestion of slaughterhouse wastewater sludge: effect of initial sludge pH. Bioresour. Technol. 259, 67-74.

Yuan, D.H., Guo, X.J., Wen, L., He, L.S., Wang, J.G., Li, J.Q., 2015. Detection of Copper (II) and Cadmium (II) binding to dissolved organic matter from macrophyte decomposition by fluorescence excitation-emission matrix spectra combined with parallel factor analysis. Environ. Pollut. 204, 152-160.

Zhao, D., Juhasz, A.L., Luo, J., Huang, L., Luo, X.S., Li, H.B., Ma, L.Q., 2017. Minera dietary supplement to decrease cadmium relative bioavailability in rice based on a mouse bioassay. Environ. Sci. Technol. 51, 12123-12130.

Zhao, X., Huang, J., Lu, J., Sun, Y., 2019. Study on the influence of soil microbial community on the long-term heavy metal pollution of different land use types and depth layers in mine. Ecotoxicol. Environ. Saf. 170, 218-226.

Zhang, S., Tian, K., Jiang, S., Jiang, H., 2017. Preventing the release of $\mathrm{Cu}^{2+}$ and 4-CP from contaminated sediments by employing a biochar capping treatment. Ind. Eng. Chem. Res. 56, 7730-7738. 